Article

\title{
Sharing Is Caring, but Is the Shore Cared for? The Sharing Paradox of the French Coast
}

\author{
Stephan J. Hauser $1, * \mathbb{D}$ and Catherine Roche ${ }^{2}$ \\ 1 Department of Architecture, Faculty of Architecture and the Built Environment, Delft University of \\ Technology (TU Delft), 2628 BL Delft, The Netherlands \\ 2 ULR 4477-TVES-Territoires Villes Environnement \& Société, Univ. Littoral Côte d'Opale, \\ Université de Lille, F-59140 Dunkerque, France; catherine.roche@univ-littoral.fr \\ * Correspondence: s.j.hauser@tudelft.nl
}

Received: 30 September 2020; Accepted: 5 November 2020; Published: 10 November 2020

\begin{abstract}
Coastlines have long attracted industrial activities, services, housing, and tourism. At select geographic locations, harbors host port facilities and provide local economic growth opportunities. As such, these areas also concentrate populations around the world. In the north of France, where the unemployment rate is high, port industries are still massive providers of work. However, in the last decades, the port development has become a major threat to the architectural heritage, the historical scenery, and the unique biodiversity of these areas, both at sea and on land. The impact of urban redevelopment has been clearly visible since 1950. At this point, this paper raises the following question: How is it possible, in this context, to efficiently limit this urban sprawl through legal frameworks to protect land, sea, and their in-between environment, in spite of the economic interests? The urbanization of the northern coastline of France has gradually expanded since 1950 until a fundamental act appeared in 1986, the Shoreline Act "Loi Littoral". This act allows us to analyze the last thirty years of urbanization and its binding force towards the protection of the environment; and yet, we also understand that it has a limited role. It does not forbid all kinds of construction, but just new buildings coming out of nowhere, though expansion in urbanized areas is allowed. After decades of existence, this framework has been integrated by both politicians and citizens, and its results have been judged. If the law is now seen as a guardian of the shore, inhabitants and environmental organizations have often criticized its dimness, which favors interpretation. This paper analyzes the soft limitations that have affected the ongoing space consumption since the 1950s using aerial pictures provided by the IGN (Institut National de l'Information Géographique et Forestière), as well as if the rules were efficient enough in their protection.
\end{abstract}

Keywords: environmental history; environmental protection; law; port city; urban history; urban planning

\section{Introduction}

The post-war urban sprawl linked to the economic renewal of the 1950s put a lot of pressure on port cities and coastal areas. The urban and industrial expansion related to the post-war economic and demographic explosion went together with a great need for space along the shore when many coastal cities in France and in Europe needed to be completely rebuilt. The port city of Dunkirk, for instance, on the north coast of France near the Belgian border (Figure 1), was subject to high levels of destruction during the war, which conversely presented new opportunities to develop innovative urban strategies.

This urban extension was supposed to come to an end with the creation of the Shoreline Act "Loi Littoral" in 1986 in the French legal system (Law No. 86-2 of 3 January, 1986 relating to the planning, protection, and enhancement of the coast, or "à l'aménagement, la protection et la mise en valeur du littoral") [1]. The government realized the importance of protecting ecological environments from 
pollution, transformation, and space consumption in order to promote tourism. To face this unregulated and ongoing expansion, the government reacted with strict limitations to new constructions in coastal cities. This Shoreline Act became a turning point in French legal history and coastal urban planning, in which the French system created and applied fundamental principles for environment protection and urban limitation.

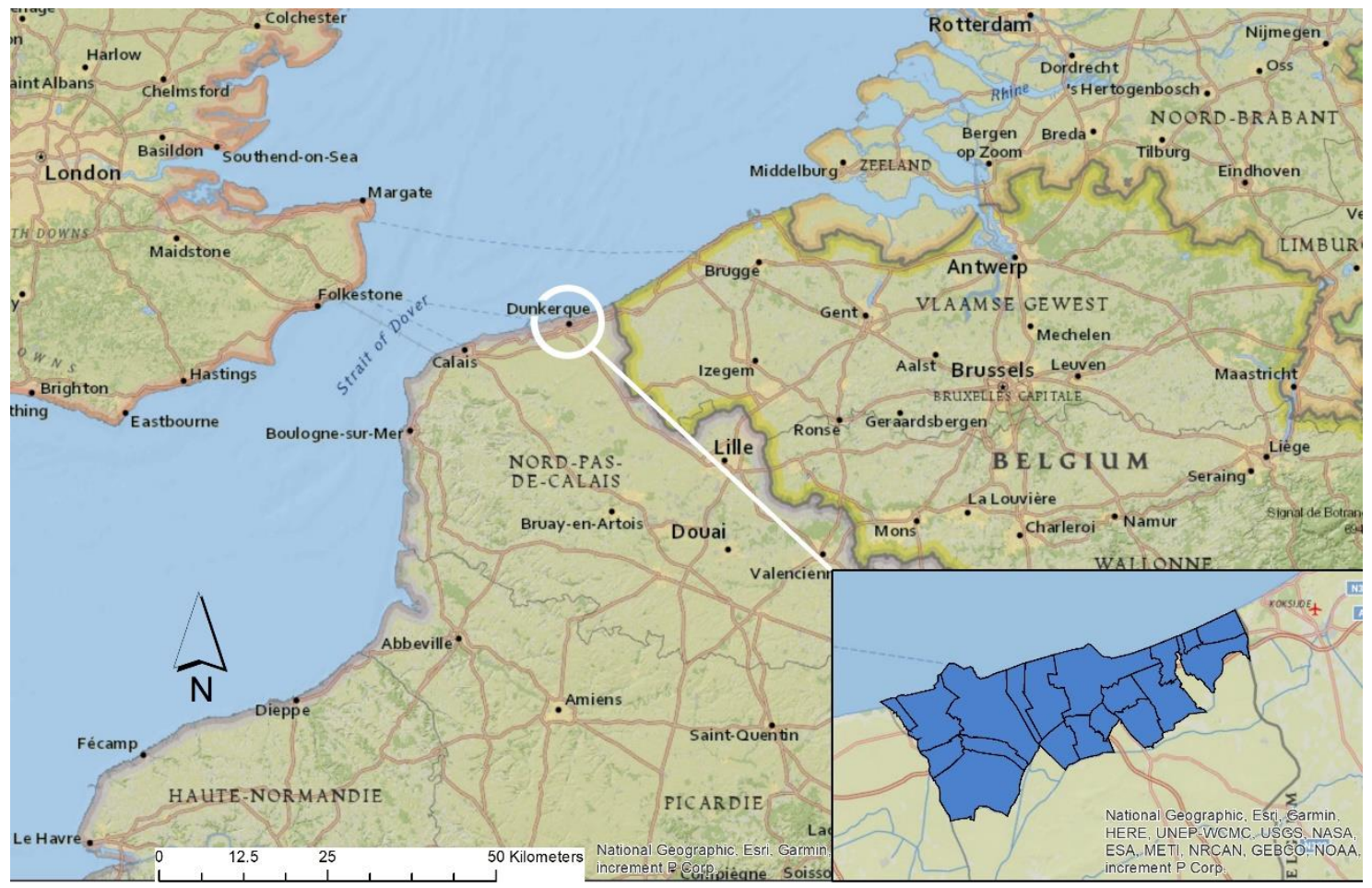

Figure 1. Map of the North Sea coast of France and Belgium with the location of the metropolitan area of Dunkirk and its neighboring environment. Map made using ArcGIS with the Basemap of the National Geographic and an online database on Dunkirk.

The enactment of such a law seemed to intervene late, yet the priority of public authorities was economic before being environmental. As a result, at a time where the protection of the environment and sustainable development were not yet implemented, the area underwent a huge urban expansion without many restrictions. Port cities expanded dramatically during this period due to the arrival and development of predominantly petroleum-based industries, which subsequently reshaped the coastal image as well as cities' environments. The consumption of natural spaces around coastal cities was the first consequence of this horizontal development, and it is now seen by public authorities and urban planners as the main challenge on the way to environmental sustainability. All the main port and coastal cities in the northwest of Europe had to contend with this planning issue, as these areas are strategic for both national economies and industry.

The main purpose of this paper is to illustrate the influence of this law, among others, on the urban development of the coast. This article discusses the protection provided by the Shoreline Act (and its subsequent revisions and interpretations) and asks: How has the law managed to limit urban sprawl along the French Sea Coast? To illustrate the influence of the law on coastal urban planning, the article focuses on the northern region around Dunkirk and its coast to later compare it with a southern region of France. The industrial pressure around the North Sea and the touristic one along the Mediterranean Sea produced different results with respect to the application of the act. Still facing a lot of pressures compared to the north, southern coastal cities tended to adapt the law according to their need for new urban areas [2,3]. Through such an analysis, the paper goes further on to ask how contemporary challenges linked to sustainability were incorporated into the legal protection of the French coast. 
According to the general approach on this subject, this new rule-what some authors have referred to as a "revolution" [4] — has halted space consumption, forcing cities to modify their urban policies towards densification. For others, this measure and the later revisions have clearly modified the view on the coastal planning through the protection of the natural environment. However, in spite of and also thanks to its lack of precision, the law has efficiently tackled the urban extension of coastal cities.

\section{Theory and Methods}

\subsection{Objectives}

The starting point of this analysis will be the post-war context and the redevelopment of Dunkirk. This time period allows us to observe the evolution of the urban landscape of the port city in relation to industrial development and the lack of consideration towards the natural environment. The paper uses differences identified in aerial pictures before and after the implementation of the Shoreline Act to illustrate the economic and urban pressure around coastal areas. The aim is to highlight the influence and efficiency of legal rules when it comes to limiting urban and industrial extensions in natural but strategic places. The sharing of space between economic, touristic and urban interests in port cities makes their planning complex and dependent on clear and reliable rules.

The point is not limited only to the port city of Dunkirk in France. Land management issues are similarly shared in coastal places where environmental protection is in competition with urban and industrial or economic development. The French port city and legal system taken as examples in this article are an illustration of reactive and protective rules related to the environment in Europe. They also demonstrate the impacts of past planning practices—or their absence—and their continuous influence on contemporary planning strategies.

\subsection{Theory}

The special characteristics of port cities, their spatial planning, and their economic impacts on an entire region have to be highlighted. Mega emphasized this crucial role of coastal cities, the risks they have to face, the opportunities that they represent, and their link to local and global citizens in a book published in 2016 [5]. Through a diversity of examples, she demonstrates the widespread benefits of port cities on both local and regional scales, as well as the importance of holistic policies to regenerate coastal cities. Recent developments linked to climate change and maritime activities are threats to the sustainable planning of coastal areas. Such dangers back Mega's argument on the need for anticipative strategies and the efficient enforcement of rules to protect and ensure the sustainable development of coastal areas.

The literature explained the difficult application of inclusive policies in French coastal management since the 1970s. In 1974 Dewailly and Barbaza illustrated this complexity through conflicts in Dunkirk's land uses [6]. They defined this situation as a competition for land between agriculture, tourism, industry, housing, and the natural environment. Building on this conflictual description, in 2004, Deboudt exposed the paradox of tourism in the port city: It is highly dependent on the natural heritage and landscape of the coast, though its development participates in its artificialization [7]. His analysis of Dunkirk's planning documents reveals a cruel lack of foresight from public authorities who, in the 1970s, predicted a constant growth of the population until the beginning of the next century. These documents expose the visions of public authorities of the time on the environment: Here, it was a secondary concern to support the development of industrial and touristic projects. However, the economic crisis of the 1980s nipped them in the bud while greatly impacting the economy of the port city.

Authors also discussed the legal implications and interpretations of the Shoreline Act and its resilience over decades. Rézenthel, in 2016, took the opportunity of the thirtieth anniversary of the law to analyze its inclusion in the French legal system and the jurisprudence around it. By pointing out the 
lack of precision and definitions in the notions created, he emphasized the importance that courts have in filling the gaps left by lawmakers [8].

\subsection{Methods}

The analysis used in this paper is based on the literature discussing the development and protection of coastal areas in combination with regulations, jurisprudences, and aerial pictures. The piece observes the efficiency of the Shoreline Act through comparative pictures of coastal areas before and after the implementation of the law. Instead of only assessing the strength of regulations from a legal perspective, the paper integrates geographic and socio-economic considerations to evaluate the effects of coastal protection.

The timeframe for this paper begins before 1986, in the 1950s, in order to more adequately comprehend the impact of the act on urban development practices. Through this historical analysis, in parallel with an account of legal developments and scrutiny of aerial photography of the area, the investigation determines the impact on coastal urbanization and the value of environmental protection, as well as the efficacy of legislation as a tool for urban development regulation.

The "IGN" (Institut National de l'Information Géographique et Forestière or National Institute of Geographic and Forest Information, in Saint-Mandé, France) provided the geographic data that allowed this examination. Its online services "Géoportail" and "Remonter le temps", which literally means "go back in time", deliver accurate and qualitative aerial pictures of the French territory $[9,10]$. The historical service provides pictures of Dunkirk and the south coast since 1920 until today, although some years are missing and the coverage is not necessarily complete each year. The software Inkscape helped to observe the changes in land use through the different pictures by creating shapes around the places where transformations were obvious. The different scales and locations of the maps made it difficult to accurately design the shapes, but existing roads, buildings, and farm lands across time confirmed their positions.

Dunkirk is the case study upon which the efficiency of protective regulations is investigated. The touristic Mediterranean region of France is later discussed to highlight the importance of different kinds of pressures on the application of the law. On the one hand, public authorities considered southern coastal areas of prior importance for urban development in order to support the touristic attractiveness of the country. On the other hand, the French government always considered the port city of Dunkirk a strategic place, and a potential competitor to its Belgian and Dutch counterparts of Antwerp and Rotterdam. The growth and economic downturns that Dunkirk experienced and the analysis of this paper are transferable to other French coastal cities and, to some extent, to other European coastal areas. Governments and institutions in Europe used similar approaches in the creation of environmental laws and the development of their coastal areas to allow flexibility and avoid strict and limiting protections on their territory.

\section{The Renewal of the Post-War Era}

Due to bombing raids from both sides during World War II, 70\% of the port city of Dunkirk was destroyed, and only a third of the population came back in 1946. The reconstruction of Dunkirk represented a great opportunity for a renewal with new urban strategies and architecture for the most important French port of the north coast. This rebuilding was entrusted to Jean Niermans, chief architect, and Théodore Leveau, responsible for the town planning, with new concerns for health and urban quality. Niermans and Leveau had opposing visions: The former wanted to completely rethink the city, while the latter was attached to the traditional architecture of the port. Leveau's approach prevailed, leading to a clear division between dwellings and industries. This division allowed the renewal of the original aspect and network of the city, as well as a port area dedicated to modern industries [11].

Unlike its neighbor, Belgium, France has a large coastal area, which prevented the complete consumption of the coastal land by urban development. However, the population growth and the attractiveness of the coastline-due to its quality of life and the rural exodus—led to a dramatic 
consumption of space between 1950 and 1980 to meet the need for housing. These thirty years before the Shoreline Act are referred to as "The Glorious Thirty" in France [12]. The term refers to years of full employment, economic growth, and an increasing industrial production and demography from 1945 to 1973. Private and public investments combined with affordable energy (fossil fuels) in France, but also in many other countries, supported this economic renewal of Western countries. Then, two successive oil shocks occurred in 1973 and 1979, and put an end to this prosperous growth.

During this time of wealth, the population of Dunkirk increased from 10,575 inhabitants in 1946 [13] to 99,776 in 1975 [14]. This demographic explosion was a serious challenge for the public authorities of Dunkirk and necessitated the construction of numerous dwellings. This urgency was illustrated through the creation of container houses right after the war to deal with the lack of housing. The real estate pressure coming from this need gave rise to the aforementioned urban expansion and, ultimately, to the creation of stringent town planning regulations. The port renewal in 1950 and the extension added between 1960 and 1970 attracted many industries-iron and steel, oil storage, and refineries-with their need for space and infrastructure. This economic opportunity brought by governmental investments to revitalize the port [15] led to the creation of a sea basin in the port, as well as new locks for industries, enacting the transformation of the port landscape.

The comparison of aerial pictures from 1949 and 1963 clearly demonstrates the urban expansion on the west part of Dunkirk (Figure 2), as well as the development of the port with new water facilities and oil-related buildings in the 15 years following the war. The economic renewal and all its opportunities are clearly visible on the landscape; it completely reshaped the west part of the port. Industrial settlements also came with their need for workforce, causing small areas near the port to develop. These former villages became cities, hosting the workers who came from across the region to work and live in this newly active coastal area. These growing cities, along with the renewal of the port, allowed an improvement in the quality of life of the citizens. Before the Second World War, for most of the population, the sanitary living conditions were alarming; thus, the reconstruction of the city was an opportunity to improve the situation with better housing and urban facilities [11].

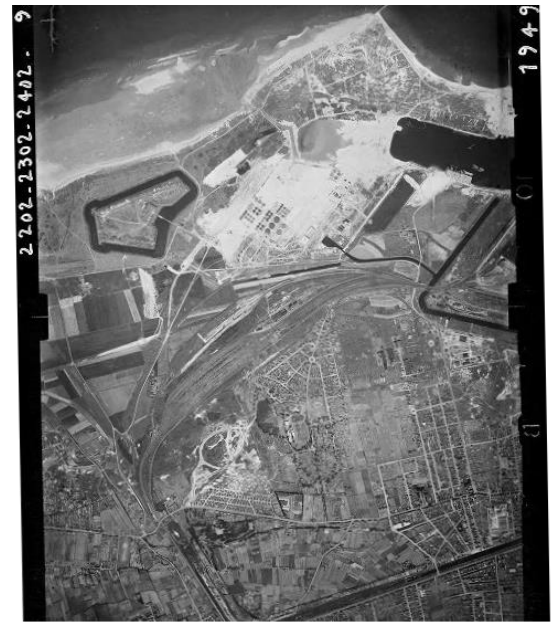

(a)

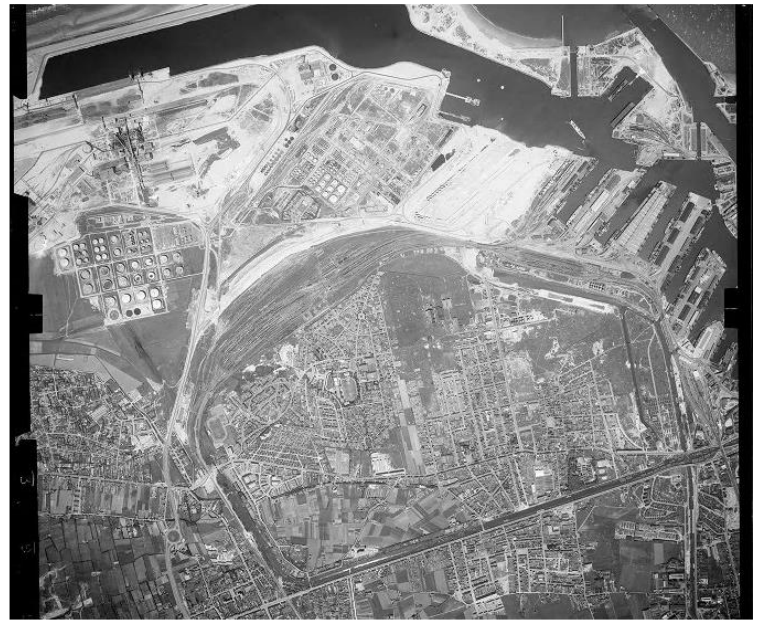

(b)

Figure 2. Aerial picture of the west part of the port of Dunkirk, Saint-Pol sur Mer. (a) The western part of the port city in 1949; (b) The western part of the port city in 1963. Pictures of the service "remonter le temps" from the French National Institute of Geographic and Forest Information (IGN).

The expansion of the city was enhanced by the attractiveness of its environment and geographical position. The coastal area attracted people dreaming of a better way of life as well as companies and industries that wanted to benefit from its facilities and networks. This pressure on the land consumed more and more spaces to solve the arising conflicts between tourism, agriculture, industry, built environment, road and railway infrastructures, and nature protection. 
The urban sprawl from the post-Second World War era consumed a critical amount of natural spaces and resources (sand, dunes, swamps). These natural environments provided water, air, and soil cleanup and biodiversity to the city. In the eastern part of the city, the town planning and the touristic tradition of this area provided a protection for the landscape. This wild area was preserved as a leisure space for the citizens of Lille and its region. With this urban expansion and the modification of the shore on the west part of the port, the sand dunes on the east of Dunkirk became vulnerable. The new infrastructures accentuated an erosion of the coast already observed after the war because of the sea flow modification it caused. The best illustration of this effect was the loss of sand and the crumbling of blockhouses on the eastern beach. However, if this part of the city had a strong culture of tourism, it was not as strong as the influence of the port and the industries in the west, where no other activities could have challenged them. In the eastern part, tourism and nature protection had to deal with the other forms of pressure (dwellings, services, agriculture, network, etc.), which took their toll on the natural landscape [6].

Two aerial photographs from 1957 and 1985 reveal the transformations in the east part of Dunkirk (Figures 3 and 4): Between 1957 and 1985, the sand dunes were replaced by houses. From 1985, the only area where nature still had a place on the coast was between the remaining dunes until the Belgian border. This extension of both the port and the city, combined with population growth, illustrated the economic renewal of Dunkirk as well as incoming threats to the natural environment. However, simultaneously, it demonstrated the lack of protection for this dedicated touristic space against the expansion strategies of local authorities [7].

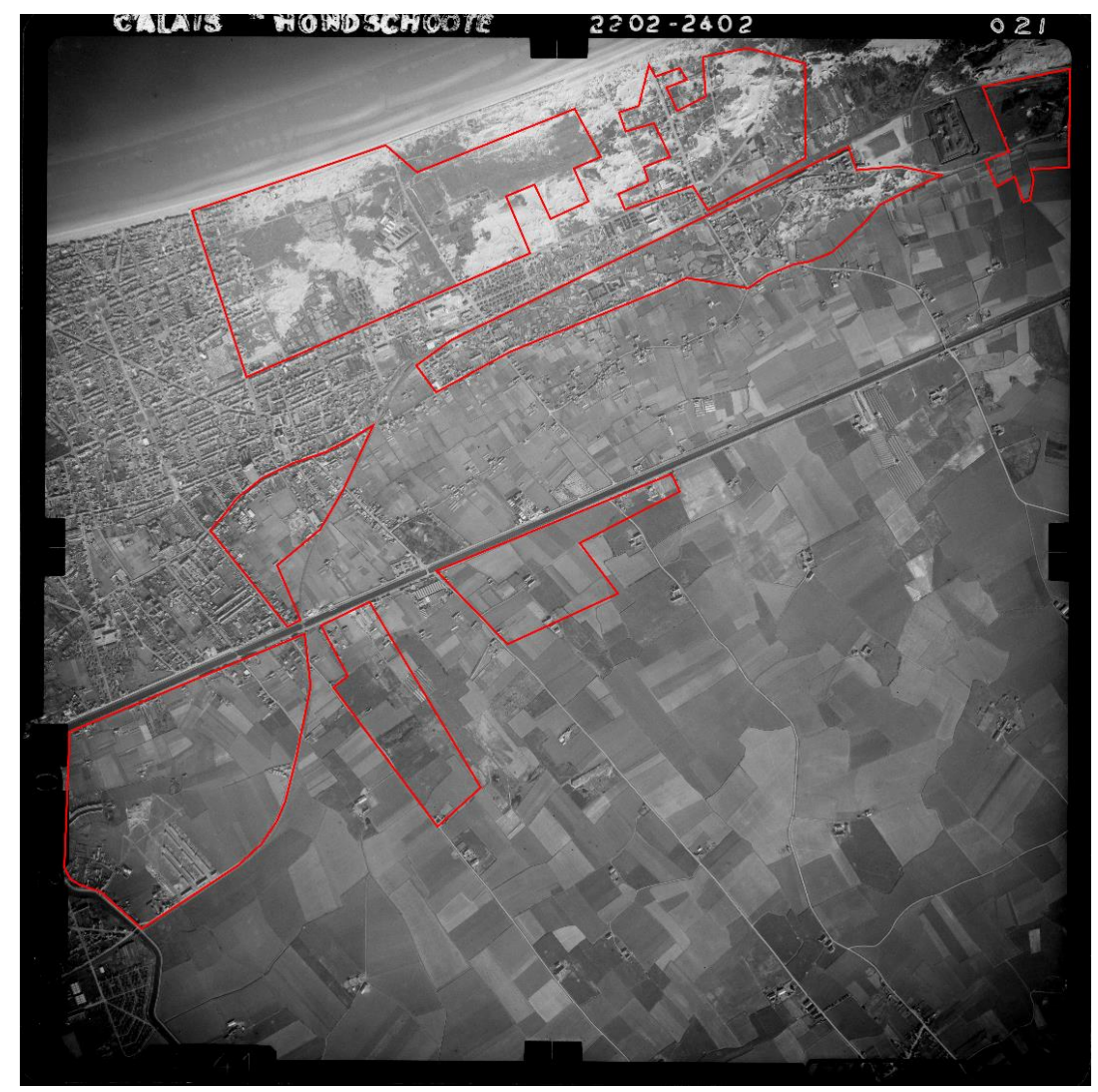

Figure 3. East part of Dunkirk, Leffrinckoucke, in 1957, with shapes of future extensions and densification of the city highlighted in red. Picture of the service "remonter le temps" from the French National institute of Geographic and Forest Information (IGN). 


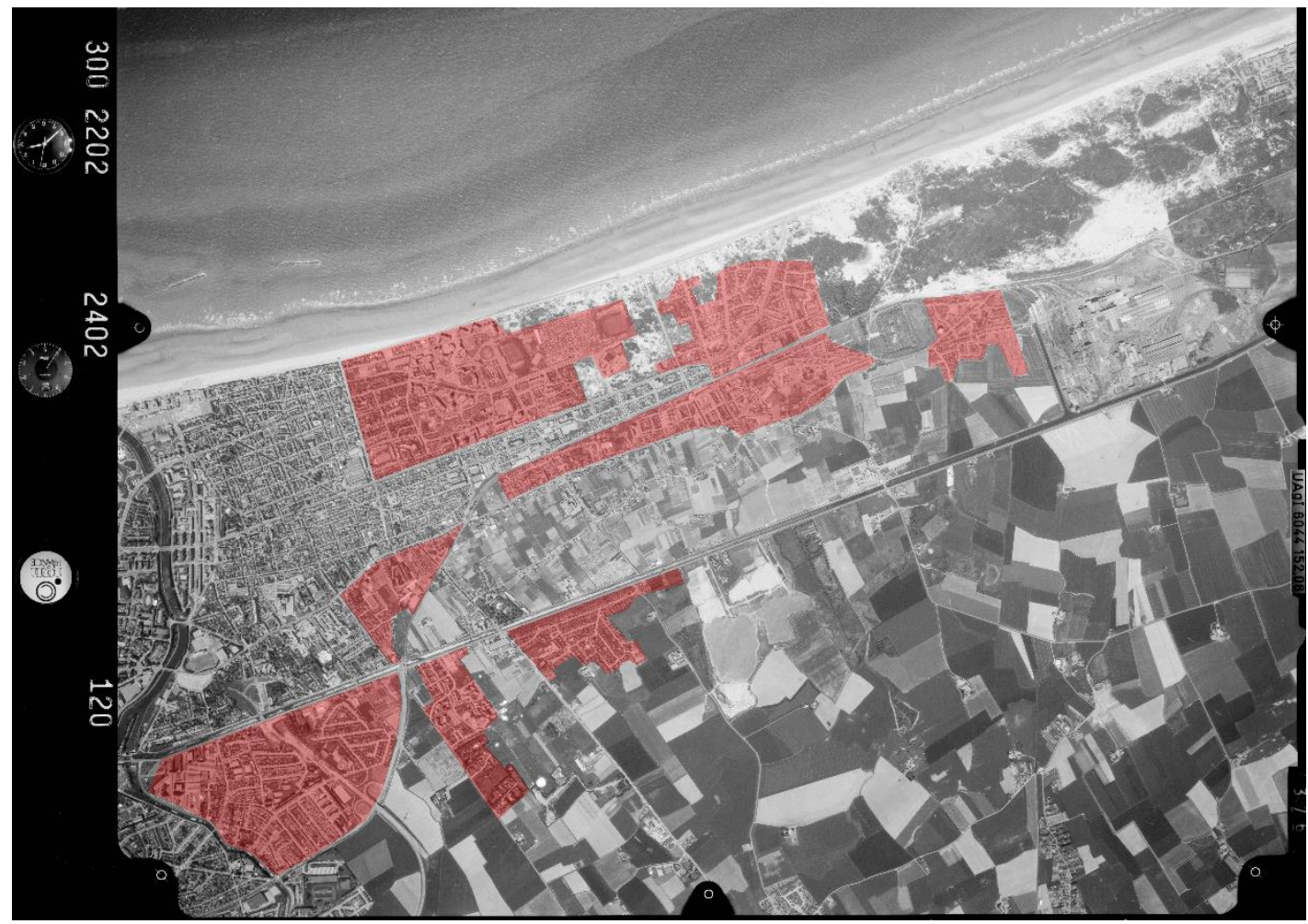

Figure 4. East part of Dunkirk, Leffrinckoucke, in 1985, with extensions of the city since 1957 highlighted in red. Picture of the service "remonter le temps" from the French National institute of Geographic and Forest Information (IGN).

In France, "The law on the protection of nature" (Law No. 76-629 of 10 July 1976 "Relative à la protection de la nature") and "The law on classified installations for environmental protection" (Law No. 76-663 of 19 July 1976 "Relative aux installations classées pour la protection de l'environnement", or ICPE) in 1976 were the founding of an environmental safeguard; with these two supports, the environment became increasingly integrated into the French legal system. In spite of this new consideration for nature protection, urban sprawl continued until 1985 in Dunkirk, threatening the last natural area between the city and the border. The services of the "Géoportail" allowed the measurement of the surface transformed in these red areas on a contemporary map of Dunkirk [9]. Though only approximative, the surface considered in Figure 4 is $24.4 \mathrm{~km}^{2}$ according to this tool. Similarly, the patches where land use changed from natural to urban areas represents around $3.78 \mathrm{~km}^{2}$. In other words, public authorities allowed $15.5 \%$ of available land in this area to be transformed in less than 30 years.

\section{The Slow Rise of Environmental Protection before 1986}

\subsection{The Missing Focus on Coastal Protection on International and European Levels}

The international and European movement on environmental protection in the 1970s also influenced French policies. The new interest in protecting natural landscapes in the 1970s was connected to wider discussions concerning energy depletion and the impact of economic growth and consumption. The subject of environmental protection became more visible in the legal domain, especially on the international level, where more than 300 treaties have been created since the 1970s [16].

Though the 1970s were the starting point of worldwide awareness on this subject, some regional and international agreements predated this movement. The "Agreement Concerning Pollution of the North Sea by Oil" in 1969 is one of them. This agreement illustrated the course of action in the creation of protective policies in the international level. Not only were they reacting to disasters, but they were also based on pollution issues. At the beginning, authorities considered coastal protection only through 
the lens of maritime pollution because of more regular incidents linked to the development of maritime transport-especially petroleum flows-until the middle of the 1970s [17]. The 1969 agreement was, for instance, reacting to the sinking of the Torrey Canyon in 1967, which affected French and British coasts. Another example of coastal protection related to pollution considerations was the Barcelona Convention, or "Convention for the Protection of the Marine Environment and the Coastal Region of the Mediterranean", of 1976.

Reports such as the Meadows report in 1972 [18] and the beginning of world conferences dedicated to nature, such as the Stockholm Conference of 1972-a United Nations decennial meeting between world leaders to enhance the sustainable development of the world-supported this rise of environmental protection internationally. However, though the Earth Summits were created in 1972, the most influential in policy terms was the Rio Summit of 1992. By this time, in the environment of Dunkirk, the urban sprawl had already consumed most of the shore and beyond; the port gained land on the sea, and the city expanded inland. Southern coastal areas experienced a similar but continuous urban expansion to accommodate the growth of tourism. Public authorities long considered reports on sustainability and the course of action in the Western world doomsday fantasies, while many private actors knew about their polluting activities [19-21]; politicians and company owners believed that the economic explosion of the "Glorious Thirties" would last. This feeling transpired in international texts, as their focus was mainly on maritime rather than land pollution. They also ignored the urbanization and its impacts on the coast, as it was in the hands of national governments.

At the European level, the first programs of action were set out in 1973 by the European Economic Community (International organization gathering European countries and later included in the European Union) [22,23]. Constraining rules on environmental quality appeared few years later with, for instance, the "Directive on drinking waters" in 1975 (Council Directive 75/440/EEC of 16 June, 1975 concerning the quality required of surface water intended for the abstraction of drinking water in the Member States) or the directive on birds in 1979 (Council Directive 79/409/EEC of 2 April, 1979 on the conservation of wild birds). Environmental protection became an autonomous policy in 1985 with the "Single European Act", implementing the objective "to preserve, protect, and improve the quality of the environment, to contribute towards protecting human health, and to ensure a prudent and rational utilization of natural resources" [24]. Later on, these objectives were applied to all the other policies of the community. However, the real confirmation of the inclusion of environmental concerns within the European Union objectives came with the Maastricht Treaty in 1992, with a binding aim: "Community policy on the environment shall aim at a high level of protection" [25]. As a member of the European Union, formerly the European Economic Community, France had to integrate these new supra-national policies and rules into its own legal system.

\subsection{Early Considerations and a Lack of Efficiency: French Coastal Protection}

In order to understand the influences behind the creation of the Shoreline Act and the development of Dunkirk and other important port and coastal cities in France, a historical analysis is necessary. The ways that contemporary protections related to the environment are designed by public authorities in France and in Europe followed a similar pattern. Many of the rules public authorities enacted to protect natural spaces were reactions to practices or incidents. The chain of events needs to be investigated to understand the obstacles and the slowness in the creation, application, and modification of regulations on coastal protection.

With the fame of the Shoreline Act, people tend to think that authorities were not valuing the preservation of the coast. In fact, consideration of the coastline as an area to be protected and the adoption of the law were the result of a long reflection. Traditionally, the first text cited in the legal field is the 1681 naval ordinance known as "de Colbert" (Louis XIV's Secretary of State for the Navy), which prohibited buildings and established free access to the shore for all. This free access is now guaranteed in article L321-9 of the Environment Code and in articles L 121-31 et seq. of the Town 
Planning Code, which provide for a right of access to beaches and a three-meter longitudinal right of passage on all beaches for pedestrians.

Portions of the coastline could be protected by the creation of national parks-the Port-Cros national park was created in 1963-or regional natural parks, for example. However, the procedures were long and complicated. Common town planning law did not make it possible to protect an area that, from the 19th century onwards, became attractive first to the wealthy social classes and then to the population as a whole. The number of buildings increased, and the question of coastal protection was not raised until the 1960s. At that time, it was less a question of protecting the sites than of guaranteeing access for all to the beach and the sea.

One of the causes of the change was the dyking concession scandal. In France, the public maritime domain (defined today in Article L 2111-4 of the General Code of Property of Public Persons) is inalienable. However, in application of the law of 16 September, 1807, some of this land could be transferred to property developers. Thus, private persons obtained a concession from the State in order to withdraw land from the action of the sea and then subsequently bought these lands at the original value. This exceptional procedure had become the rule. The law No. 63-1178 of 28 November, 1963 related to the maritime public domain could not prevent the construction of marinas, especially in southern regions, despite extending the maritime public domain. However, it provided for the creation of land reserves: Private land could be "reserved for the satisfaction of needs of public interest, maritime, seaside, or tourist (...)", renewable for a period of five years. No construction or extension of construction was possible on this land. Unfortunately, this provision was little used and then abandoned. Eventually, a circular of 3 January, 1973 limited the dyking possibilities and prohibited the transfer of ownership of exposed lands to private persons. Judges supported this prohibition, especially thanks to the jurisprudence of the Conseil d'Etat (the highest body for administrative justice) (20 May, 1977, No. 94212 and No. 89943, Paoli and Committee for the defense of the site of the Forêt-Fouesnant; 30 March, 1973, Schwerztoff No. 88.151), which put an end to this practice.

It is, therefore, false to say that public authorities did not take coastal protection into account before the 1986 law, but these isolated initiatives did not make it possible to define a comprehensive policy for the protection and development of the coast. It was difficult for national and local authorities to reconcile the desire to allow the greatest number of people to access the shores, the development of economic activities, and the preservation of the natural character of the coastal sites. Moreover, from the 1950s onwards, major development projects were carried out or encouraged by the State in order to promote access for all to seaside leisure activities, as well as major port development projects.

The first success in protecting the coast was the creation of the "Conservatoire du Littoral et des Rivages Lacustres" (Conservatory of Coastal and Lake Shores-law No. 75-602 of 10 July, 1975). This administrative institution set up protection by land management. The Conservatory acquires or receives the land as a gift or bequeathment, but does not directly manage the land, which it entrusts to a local authority, public institution or foundation, or approved specialized associations. The land acquired is subject to a management plan, and "within the limits of their vocation and their fragility, they may be open to the public" (art. L 322-1 and following of the Environmental Code). The Dunkirk coastline benefited from the action of the Conservatory on four of its dunes and even on former industrial wastelands (http://www.conservatoire-du-littoral.fr/).

In 1973, the government received a report commonly referred to by the name of the chairman of the study group on the French coast. The "Piquard Report" laid the foundations for modern coastal development with, for instance, recommendations for the creation of the "Conservatoire du Littoral". It also proposed the principles of coastal development, which would eventually be incorporated into the Coastal Law, like: in-depth development where coastal areas and their hinterland are considered as a whole and "green" cuts or buffer zones for nature and agriculture. However, political decisions on such a delicate subject take a long time, and several years go by before a law is passed. It was first on 4 August 1976 that an "instruction" concerning the protection and development of the coastline and shores of the Great Lakes was adopted by Prime Minister Jacques Chirac. In fact, until the reforms 
of 1983-1985, town planning was the responsibility of the State and at the local level of the prefect (representative of the State). After these reforms, the urban planning competence was mainly granted to municipalities. The 1976 text stated that "the protection of the coast is a national imperative $(\ldots)$ "; it was necessary both to "avoid the degradation of the shores" and that they be reserved only for the better off. To achieve this, the instruction set three guidelines: avoid linear urbanization of the coast, favor constructions behind the shore so that it remains accessible to all, and provide for agricultural or natural urbanization cuts. It was replaced by the "d'Ornano Directive" (named after the Minister of the Environment and the Living Environment, and approved by decree No. 79-716 of 25 August 1979), which took up these elements and added to them-in particular-a new provision relating to the preservation of a coastal strip $100 \mathrm{~m}$ deep (Figure 5). For technical and legal reasons, these different texts were not very effective. Between the Piquard report and the Littoral law, 13 years passed, illustrating the temporality of political decisions mentioned earlier.

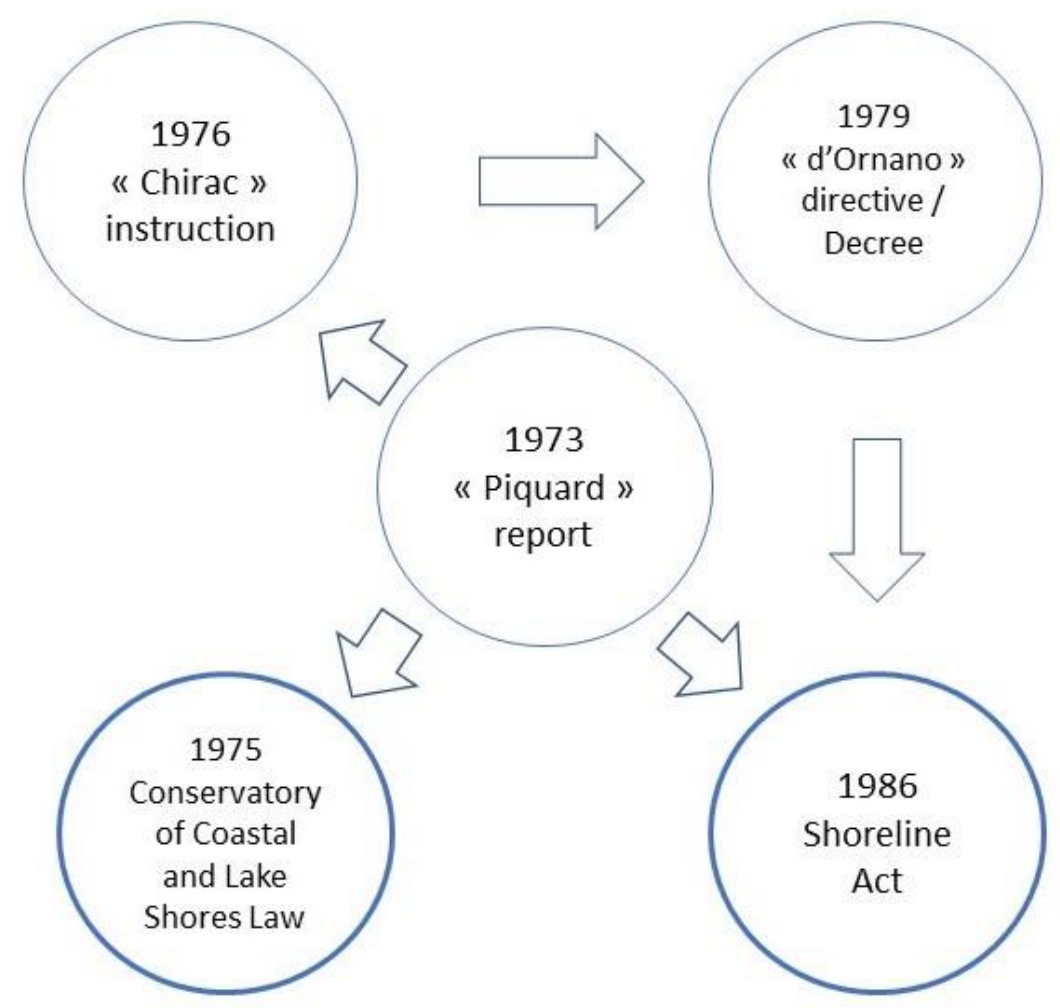

Figure 5. Diagram of the relation between the different texts that influenced the writing of the Shoreline Act. Made by Catherine Roche.

\section{Various Threats for a Limited Protection}

Environmental protection in France predates the 1970s with, among others, regulations on classified installations dating back to 1917; those on national parks are from 1960, and those on water from 1964. However, these were scattered regulations under the responsibility of different ministries without any real coordination between them and without overall vision on the protection of nature. It was only in 1971 that the French government created a Ministry of Nature and Environmental Protection (Decree No. 71-94, 2 February 1971, and Decree No. 71-245, 2 April 1971) [26]. The idea germinated in 1969, notably with the prospect of the Stockholm Conference of 1972 mentioned previously, the influence of certain high-ranking civil servants, and the trip to Chicago by French President Georges Pompidou [27-30]. The latter expressed, during this journey, a desire to "create and spread a kind of 'environmental morality' (...)" [31]. Despite some early signs, this creation came as a surprise for the French administration, including the new minister Robert Poujade (Minister from 7 January 1971 to 1 March 1974). The latter detailed how difficult the setting up of this new ministry 
was: "Every month, every week of our existence has been a struggle" [32]. Robert Poujade summed up the challenge in a remark made by a politician: "What you are doing is new, it is interesting, it may be important. But are you sure that it is not impossible?". The government limited the means of this ministry and considered it more as a ministry of impulse than of action. It will be, however, from 1976 onwards, at the origin of fundamental texts. Even if the question of coastal development did not depend on this ministry, its creation undoubtedly consolidated an emerging reflection.

The Shoreline Act in 1986 illustrated this influence over the French legal system on environmental protection. Conscious of its attractiveness for tourism and the threats that the leisure industry and other activities posed to the natural environment, France enacted two major and innovative laws for the French legal system. The year 1985 saw the creation of the Mountain Act (Law No. 85-30 of 9 January 1985, relating to the development and the protection of the mountain or "au développement et à la protection de la montagne"), which was a founding law for the future spatial planning of the country due to its multi-disciplinary nature, dealing with tourism, town planning, agriculture, and industry together. The second major law was the Shoreline Act of the following year, which was also inspired by the Mountain Act. The purpose was to transfer the main objectives from the mountains to the coasts, the two environments being similarly threatened and important for tourism. These two laws were highly influential for the development of environmental regulations-in legal and political terms-despite their limitations.

These laws operated a shift in the political way of thinking of urban planning in coastal areas, without being able to completely avoid abuses. They forced the coastal cities to change their approaches to land development, moving from a quantitative strategy to a qualitative one. The legislation and its implementation through the judicial system offered support to local associations that were trying to fight the chaotic urban development brought about by the lack of regulation. The prohibition of any construction on a hundred-meter-long stretch of the shore-from the highest point of the sea-and the protection of the local natural environments, formerly seen as potential urban lands, led to a deep change in urban strategies. However, these legal dispositions often came with exemptions and unclear definitions, allowing interpretations to avoid some of the protections. While this Act could have been considered as demonstrating strong political will to protect the coastal environment, the lack of precise definitions of terminology, as well as the numerous exemptions, illustrated the reluctance of politicians to involve themselves in a regulation that impacted the economic growth of cities.

A translation and definition difficulty must also be pointed out. In the 19th century, the French word "littoral" replaced the previously used word "rivages". However, the Shoreline Act does not define "littoral", and no specific English word matches the understanding of the notion; the current Article L 321-1 of the Environment Code only states that, "The littoral is a geographical entity which calls for a specific policy of development, protection, and enhancement." The following article defines what a coastal municipality is. In fact, the law applies not only to the coastline (the term used by the European Union), but to the entire territory of the coastal municipality. The strict legal frame it creates can, exceptionally, push municipal authorities to abandon parts of their territory in favor of a neighboring commune, such as the commune of Plouvien in 2015 with land adjacent to an "aber" or ria (estuary of a small river). This transfer allowed it to escape the status of a coastal municipality subject to the law of the same name. This is due to the fact that the law "specializes the coastal land area in specific zones with regard to the proximity of the sea or the functioning of coastal activities" [33]. The limitations to town planning are different according to the distance from the sea and the characteristics of the area in question, but they exist throughout the coastal municipality, even on its hinterland. Thus, coming back to the terminology, the "Littoral" law is not a law of the shoreline, but rather one of "coastal municipalities".

The full title of the Act already demonstrates the contradictory economic and protection objectives linked to coastal areas: "the planning, protection, and enhancement of the coast." Some local politicians see it as a law for planning and development, while judges, associations, and residents see it as a law for the protection of the environment, yet it is both. The reluctance of politicians-including national 
ones-is illustrated by the very late adoption of decrees, particularly those relating to municipalities bordering estuaries, which are considered to be coastal municipalities under certain conditions. One of these conditions is to appear on a list fixed by decree of the government. However, it was not before 2004 that such decrees were adopted, i.e., 18 years after the adoption of the law and four years after the Prime Minister was enjoined by the Conseil d'Etat to adopt them (28 July 2000 No. 204024, France Nature Environment). The search for a compromise led to a lack of political investment and caused this innovative law to suffer from unclear terms in its more relevant points. The prohibition within the hundred-meter-long stretch, for example, which starts from the shore, was limited to spaces not yet urbanized. However, there was no explanation of what was considered to be an urbanized area or how temporary installations and energy or storage facilities were to be classified in this context. Another characteristic element of the law was the prohibition of new construction in coastal cities if it did not require immediate proximity to the shore or was not contiguous to existing cities [34]. However, once again, there was no clear definition of what constituted 'proximity' and 'contiguous' development, or of the areas close to the shore, which were subject to a limited extension of urbanization. The main purpose here was more to avoid isolated constructions in the land than to prevent the expansion of the city. As long as the new buildings were close to existing structures, the city could consume the space without transgressing the law. Without clear definition, the flexible terms of the law allowed this kind of exploitation, rendering interpretation the most important rule of the law.

This last prohibition led to the creation of a vicious circle on the subject of environmental protection surrounding wind farms. To protect housing areas from the nuisance of such installations, the Code of the Environment in its article L553-1 included a distance of five hundred meters; however, when facing such cases, judges considered these installations as extensions of urbanization, and thus had to be constructed in continuity with the existing urban network [35]. In the current context of energy transition, this has ensured that private investors are unable to build wind farms due to the lack of precision in the law, despite the imperative towards renewable energies. By protecting the landscape and the local environment, the law created an impediment towards global sustainable development and sustainable energy production.

\section{One Law for Different Results}

\subsection{An Apparent Efficiency in Dunkirk}

Exemptions and mechanisms from the Shoreline Act and further legal developments enabled major modifications of the coast, in line with the "enhancement" part of the title. The construction of the LNG (Liquified Natural Gas) Terminal in the west part of the port, near the city of Gravelines and next to a nuclear plant, took advantage of these possibilities and illustrated the full potential in the use of the law. This project started in 2012, and in spite of the increased protection of nature, it transformed the landscape and consumed a great amount of natural spaces (Figure 6). However, this settlement was legal due to the "environmental offset" clause implemented by the builder; it created another "natural area" to "repair" the impact of the industrial site on the local environment. The article 20 of the Shoreline Act confirmed the use of this mechanism, later developed in national and European systems. However, the physical alteration of the coast could not be recreated in another location, and the compensation was only partial in scope and scale while introducing additional noise disturbances to the area. This case also demonstrated that such mechanisms are implemented for the richest investors. The cost induced by this clause was meant to prevent its regular use, but it had a vicious effect: The settlement of major infrastructures with a great impact on the local environment by the richest companies participated in the artificialization of the coast.

For the city of Dunkirk, these legal developments mitigated the urban sprawl. The comparison between aerial pictures of the most attractive places of the city in 1985 (Figure 4) and in 2015 (Figure 7) proves the slow-down and demonstrates this sudden change in the town planning strategy of port cities. Rather than extensions and growth, authorities had to privilege densification of existing urban areas. 


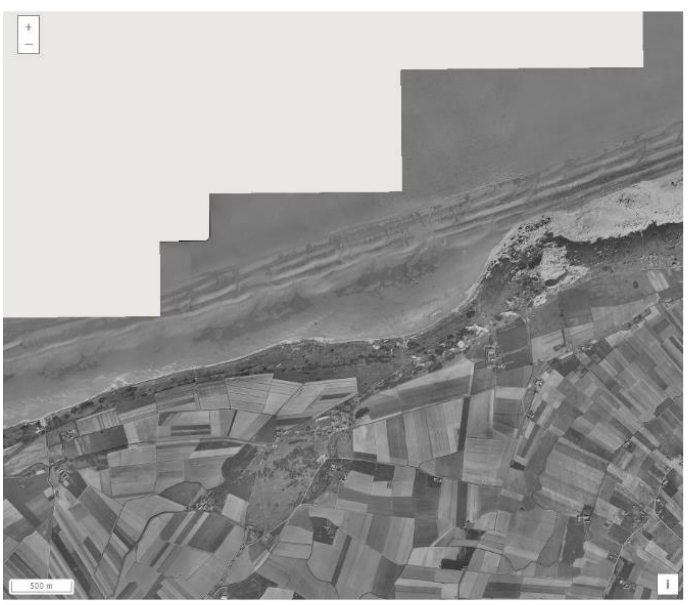

(a)

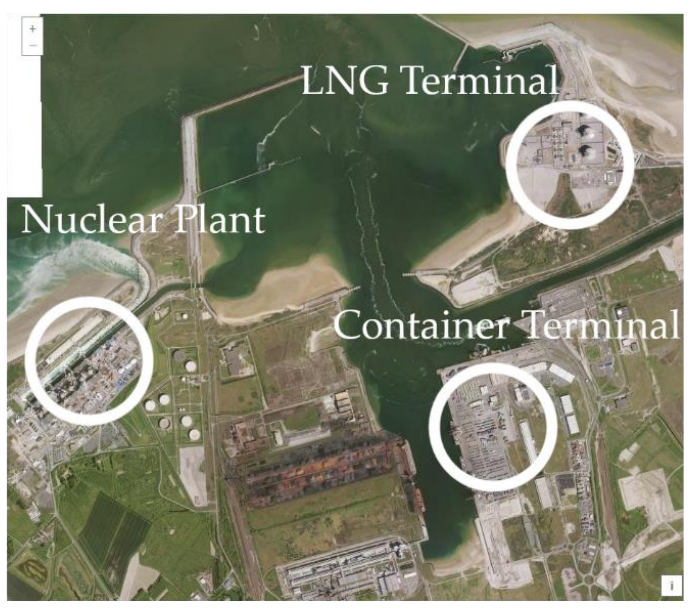

(b)

Figure 6. Evolution of the western limit of the port city of Dunkirk. (a) The landscape on the western limit of Dunkirk in 1957; (b) The landscape of the western limit of Dunkirk in 2018, with circles to highlight the settlement of the nuclear plant of Gravelines and the Liquid Natural Gas (LNG) and Container Terminal. Pictures of the service "remonter le temps" from the French National institute of Geographic and Forest Information (IGN).

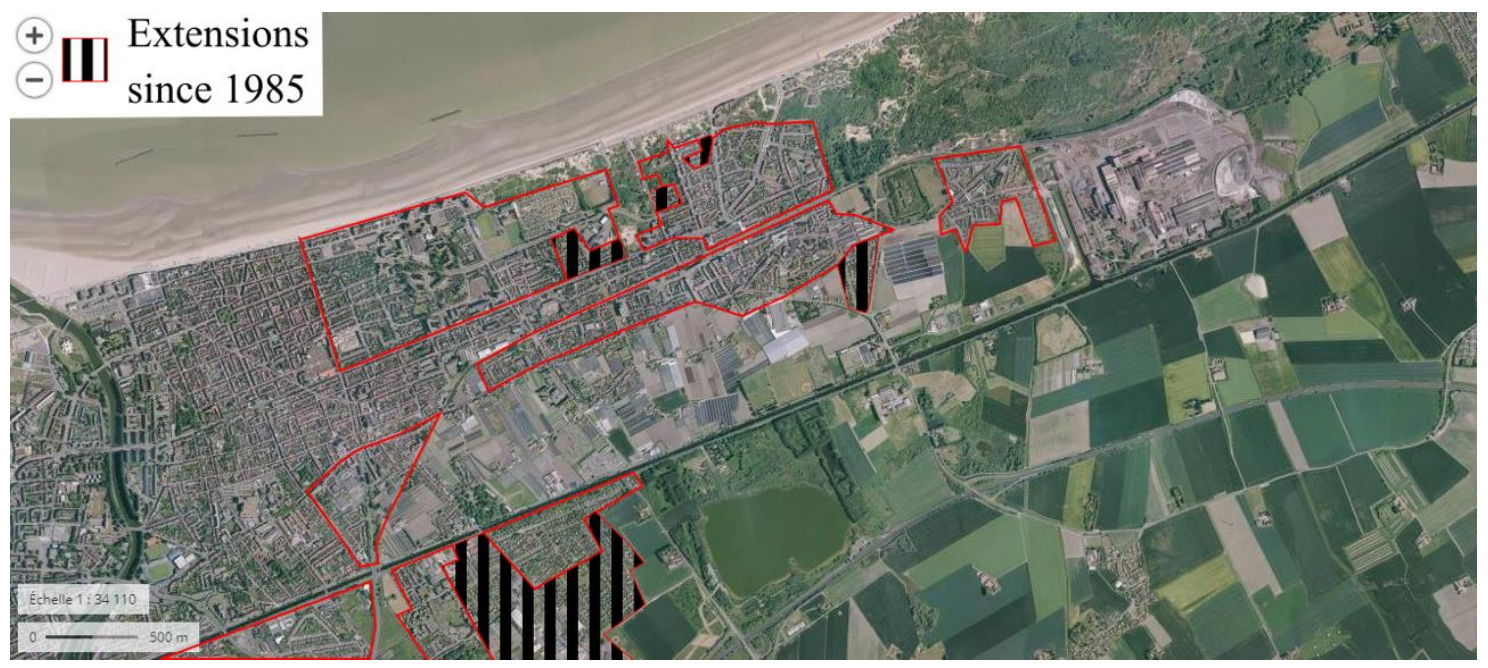

Figure 7. East part of Dunkirk, Leffrinckoucke, in 2015, with the extensions of the city after and before the creation of the Shoreline Act. Picture of the service "Géoportail" from the French National institute of Geographic and Forest Information (IGN).

Over the last thirty years, the urban consumption of space has stopped in Dunkirk. Though local and national investments supported the settlements of new infrastructures in the port thanks to the Shoreline Act ignoring port areas in its limitations, the size of the city did not change like in the previous thirty years. The legal framework can explain this result, but cannot be considered as the only factor. The economic context of this area is not the one of "The Glorious Thirty" anymore. The industrial sector struggles to maintain its activities, and the oil facilities (refineries and storage) are closing one after another. Even if new industries settled-like the LNG terminal—the decreasing population since 1982 demonstrates the difficult economic circumstances (from 100,404 inhabitants in 1982 to 87,353 in 2017) [14]. In other cities on the French coast, tourism had a heavier influence than what was observed in Dunkirk back in the 1970s. In the south part of France, some cases reveal the relativity of the "rule of law" in the application of the Shoreline Act. The difference in the attractiveness of the south coast 
demonstrates that gaps and lack of precision in the law can support the urban expansion of coastal areas in spite of apparent limitations.

\subsection{The Attractive South and the Power of the Judge}

The share of artificialized land in the northern province of which Dunkirk is part-called the North-is great, especially in coastal areas. With $47.2 \%$, it is the second greatest rate in France when looking at cities along the shore. The only province above this number is a southern one, on the Mediterranean coast—called Alpes Maritimes—with a rate of artificial land reaching 59.1\%. Between 2000 and 2006, authorities allowed 1150 hectares to be developed into urban lands on the northeast coast of France-called "Manche Est et Mer du Nord" in the report-whereas, in the same period, in the Mediterranean region, new urban areas consumed 1900 hectares of land [36,37]. These statistics represent the difference of attractiveness of the two French regions, with the north being mainly an industrial place for the country, and the south a major touristic place.

The great construction pressure on the Mediterranean region of the French coast is particularly understandable when considering its topography. The area counts many hills and the mountain chain of the Alps, making it difficult to extend urban areas beyond the flat lands provided by the shoreline. This challenging territory is an additional factor to explain that within five hundred meters of the sea, $30.1 \%$ of the land is artificial, while its northern counterpart stands at $24.9 \%$ in the same area [36,37]. Thus, following the possibility of the Shoreline Act to extend in continuity with existing urban areas, cities on the Mediterranean coast densified and extended along the shore.

The southeast coast of France is a major touristic spot as well as a fashionable one due to the numerous houses of stars and businessmen implemented there. The real estate, economic, and political pressure led to a situation where almost all of the coast is urbanized, and is still being densified according to the rule of urban continuity (Figure 8). The marina of Port-Grimaud, for instance, is one of the most famous examples of private appropriation of maritime public domain before the adoption of the Shoreline Act, with its construction beginning in 1966. Public authorities and associations still consider the region as well protected because of the preserved inland forests. This results from a focalized urban extension along the coast; as for real estate developers, this land is still gold and a hotspot to develop. More than half of the litigation about the Shoreline Act originated from this region alone [4].

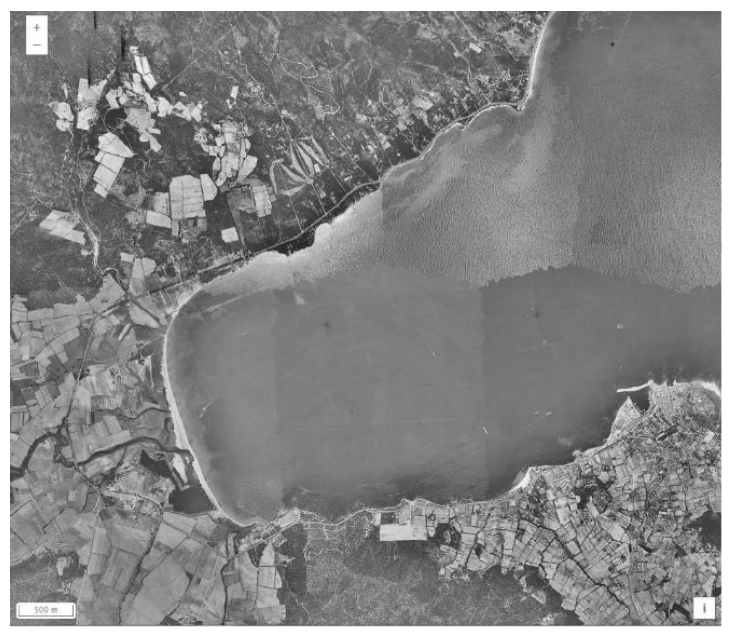

(a)

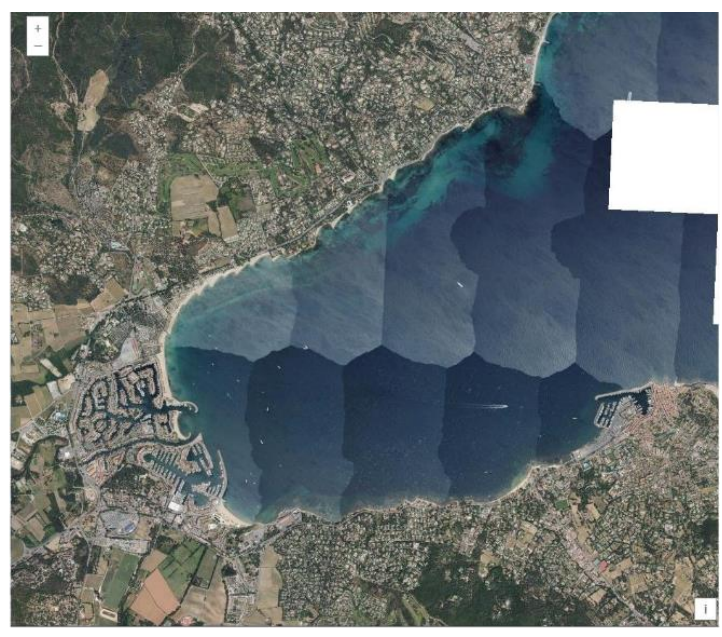

(b)

Figure 8. Gulf of Saint-Tropez in the southeast of France. (a) Landscape of the Gulf in 1955; (b) Landscape of the Gulf in 2017 with the change in the land use by the construction of Port-Grimaud in the bottom left corner clearly visible. Pictures of the service "remonter le temps" from the French National institute of Geographic and Forest Information (IGN). 


\subsection{The Power of the Judge}

Due to a lack of clarity in the definition of important notions of the law and the abundant litigation around it, judges took over the task of clarifying its application. French judges developed the understanding of the law through practical cases in which they interpreted its principles according to the context of each case. The protection of the natural environment of the coast is mainly due to their strict interpretations of natural protection and of the conditions to allow new construction. Even when economic and social considerations push national judges to accept projects, the Court of Justice of the European Union (previously the Court of Justice of the European Communities) regularly confirms that such elements cannot overcome the protection of species and natural habitats (Judgement of 11 July 1996, "Royal Society for the protection of birds", C-44/95, ECLI:EU:C:1996:297; Judgement of 7 November 2000, "Secretary of State for the environment, transport and the regions", C-C-371/98, ECLI:EU:C:2000:600) [8].

The Act, in its original form, was not seen as a long-lasting law in the French order due to its - at the time-strict limitations and the pressures it had to face [38]. As imperfect as it was, the regulation survived, and a new law adapted the old version to climate change in 2018 (Law No. 2018-1021 of 23 November 2018). The idea was not to open the coast to urbanization, but to keep the original protection of this area while allowing it to adapt itself to the upcoming change [39]. It also implemented more precision with definitions of notions that were previously unclear while lifting some contradictions.

\section{Conclusions}

The consumption of space that occurred alongside the economic development of the post-war era together with the help of rising environmental disasters alerted the authorities, forcing them to apply stricter limitations to urban expansion in coastal areas. However, many legal improvements were reactive, waiting for a disaster to change the rules; in the town planning sphere, public authorities implemented changes when space became scarce or dangerous, like the Shoreline Act with the consumption of coastal spaces. Although the Shoreline Act is imperfect and lacks precision, its limiting effects are undeniable. The Belgian neighbor, with its short coast, experienced similar pressure and could not prevent its intensive and still-growing urbanization [40].

The protection of the coast was secondary to the pressure from industries, tourism, and public authorities to implement limitations without a possible way out. The great place given to interpretation due to the lack of precise definition and limitation in the Shoreline Act permitted judiciaries to establish their own visions of the law and what should become of the protection of the natural environment and landscape on the coast [41]. The understanding of the law was open and indirectly transformed judges in guardians of the environment through their strict application of the Shoreline Act. This mechanism pushed lawmakers to make the act precise (especially through the ELAN law No. 2018-1021 of 23 November 2018 on the "évolution du logement, de l'aménagement et du numérique" or "evolution of housing, development and digital"), permitting fewer areas for misinterpretation; the decisions of the courts helped to improve the safety of local environments. However, local organizations and actors criticized this precision of the government as a way to open urbanization of coastal areas with restrictive definitions and by opposing environmental and social arguments [42,43]. Not only do regulations have to be precise in the definition of their content, but lawmakers also need to adopt a holistic approach rather than an exclusive one to meet contemporary environmental objectives.

The sustainable development of coastal areas is now more developed and discussed than ever, but still has to deal with other obstacles. The updates to the Shoreline Act brought by the new law of 2018 tackled the wind farm issue mentioned earlier, but other problems can arise. The strong attachment of citizens to the protection of their traditional landscape that tens wind turbines could affect is one of them. It pushed the settlement of wind turbines away from the land, where no continuity to urban areas was required anymore. However, since 2004 and the acceptance of the first project, no offshore 
wind turbine farms in France are operational [44]. In Dunkirk, the public debate on such a farm project started in September 2020 in a bid to improve the social approval of wind farms.

Because port cities are among the first to face the influence of pollution and climate change, they must also be the first to innovate in facing the transformation challenges of their past industrial and economic activities [45]. By dealing with real estate, economic, touristic, agricultural, and industrial pressures, they can prove the feasibility of these innovations and participate in the general notion of sustainable development. In the post-COVID context of economic renewal, governments are pushing towards the weakening of environmental regulations, creating an even more difficult situation for local authorities and actors in ensuring the sustainable development of their port cities [46-48]. These interconnections between different aspects of the socio-economic life of port cities and the need for sustainable development are a generator of the "Wicked Problems" outlined by C. West Churchman in 1967 [49]. According to this notion, the interdependencies between all these factors make them complex to resolve, since solving one may create another. However, if authorities of port cities can protect their environment while supporting economic and industrial activities in spite of unclear legal frameworks, then the example will be settled for other cities and higher levels for the energy transition to come.

Author Contributions: Conceptualization, S.J.H. and C.R.; methodology, S.J.H. and C.R.; software, S.J.H.; validation, S.J.H. and C.R.; formal analysis, S.J.H. and C.R.; investigation, S.J.H. and C.R.; resources, S.J.H. and C.R.; data curation, S.J.H. and C.R.; writing-original draft preparation, S.J.H. and C.R.; writing-review and editing, S.J.H. and C.R.; visualization, S.J.H. and C.R.; supervision, S.J.H. and C.R.; project administration, S.J.H. and C.R.; funding acquisition, S.J.H. All authors have read and agreed to the published version of the manuscript.

Funding: The research of S.J. Hauser behind this paper was funded by the Antea Group and the Learning Center Ville Durable of Dunkirk.

Acknowledgments: This paper is the development of a presentation made during the "Viscous Space North Sea Conference" of June 2018. Some ideas have been written in the context of discussions in the LDE PortCityFutures research community. It reflects the evolving thoughts of the authors and expresses the discussions between researchers on the socio-economic, spatial, and cultural questions surrounding port city relationships. We especially thank Carola Hein and Amy Thomas for their precious comments and support on this paper.

Conflicts of Interest: The authors declare no conflict of interest.

\section{References}

1. Légifrance. Available online: http://www.legifrance.gouv.fr (accessed on 7 August 2020).

2. Daligaux, J.; Minvielle, P. De la loi littoral à la gestion intégrée des zones côtières. Regard critique sur vingt ans d'urbanisation des littoraux méditerranéens français. J. Mediterr. Geogr. 2010, 115, 55-67. [CrossRef]

3. Zaninetti, J.-M. L'urbanisation du littoral en France. Popul. Avenir 2006, 2, 4-8. [CrossRef]

4. Daligaux, J. Urbanisation et Environnement sur les Littoraux: Une Analyse Spatiale. In Rives Méditerranéennes; Presses Universitaires de Provence: Aix-en-Provence, France, 2003; Volume 15, pp. 11-20.

5. Mega, V.P. Conscious Coastal Cities: Sustainability, Blue Green Growth, and The Politics of Imagination; Springer: Berlin/Heidelberg, Germany, 2016; pp. 39-62, 223-252, 253-268.

6. Dewailly, J.-M.; Barbaza, Y. Conflits de fonction dans un secteur à vocation touristique: Le littoral entre Dunkerque et la frontière belge. Bull. Assoc. Geogr. Fr. 1974, 51, 203-213. [CrossRef]

7. Deboudt, P. Tourisme Littoral, Préservation des Espaces Naturels et Gestion Intégrée de la Zone Côtière en France: Le Cas de la Côte d'Opale. Hommes Terres Nord 2 2004, 2, 37-48. [CrossRef]

8. Rézenthel, R. Les ports maritimes et trente ans d'application de la loi relative au littoral. In Droit Maritime Français; Wolters Kluwer France: Paris, France, 2016; Volume 776, pp. 65-72.

9. Institut National de l'Information Géographique et Forestière. Géoportail. Available online: https://www. geoportail.gouv.fr/ (accessed on 6 August 2020).

10. Institut National de l'Information Géographique et Forestière. Remonter le temps. Available online: https: //remonterletemps.ign.fr (accessed on 6 August 2020).

11. Lebel, A. La Reconstruction. Website of the city of Dunkirk. Available online: https://www.ville-dunkerque. fr/decouvrir-sortir-bouger/histoire-patrimoine/lhistoire-de-dunkerque/la-reconstruction (accessed on 7 August 2020). 
12. Fourastié, J. Les Trente Glorieuses ou la Révolution Invisible; Fayard: Paris, France, 1979.

13. Casevitz, J. Le recensement du 10 mars 1946. Inf. Geogr. 1947, 11, 102-111. [CrossRef]

14. Institut National de la Statistique et des Etudes Economiques. Dossier Complet: Commune de Dunkerque. Available online: https://www.insee.fr/fr/statistiques/2011101?geo=COM-59183 (accessed on 21 October 2020).

15. Tourret, P. Ports Français. Les Mutations. Outre-Terre 2012, 3, 321-331. [CrossRef]

16. Maljean-Dubois, S.; Rajamani, L. La Mise en CEuvre du Droit International de l'Environnement; Martinus Nijhoff: Leiden, The Netherlands, 2011.

17. Hay, J.; Thébaud, O.; Agundez, J.P. Marées Noires: Enjeux Economiques; Editions Quae: Versailles, France, 2008.

18. Meadows, D.H.; Meadows, D.L.; Randers, J.; Behrens, W.W. The limits to growth. New York 2004, $102,27$.

19. Jacques, P.J.; Dunlap, R.E.; Freeman, M. The organisation of denial: Conservative think tanks and environmental scepticism. Environ. Politics 2008, 17, 349-385. [CrossRef]

20. Greenhouse Effect Working Group Shell Internationale. The Greenhouse Effect; Shell Internationale Petroleum Maatschappij B.V.: The Hague, The Netherlands, 1988.

21. Center for International Environmental Law. Plastic Industry Awareness of the Ocean Plastics Problem; Center for International Environmental Law: Washington, DC, USA, 2017.

22. Roche, C. L'essentiel du Droit de L'environnement 2020-2021; Gualino: Issy-les-Moulineaux, France, 2020.

23. Baziadoly, S. Le Droit Communautaire de L'environnement depuis l'Acte Unique Européen Jusqu'à la Conférence Intergouvernementale; Éd. de l'Université de Bruxelles, Collection de Droit International: Brussels, Belgium, 1996.

24. European Union. EUR-Lex, 1998-2020. Available online: https://eur-lex.europa.eu/ (accessed on 7 August 2020).

25. European Communities. Treaty on European Union; Official Journal of the European Communities: Brusseles, Belgium, 1992.

26. Silvera, V. Le Premier Remaniement de la Structure du Septième Gouvernement de la Cinquième République. Rev. Adm. 1971, 24, 277-280.

27. Lascoumes, P. Instituer L'environnement: Vingt-Cinq ans d'Administration de l'Environnement; L'Harmattan: Paris, France, 1999; p. 233.

28. Barré, R.; Lavoux, T.; Piveteau, V. Un Demi-Siècle d'Environnement entre Science, Politique et Prospective: En L'honneur de Jacques Theys; Editions Quae: Versailles, France, 2015.

29. Comité d'Histoire, Conseil Général de l'Environnement et du Développement Durable. Les 40 ans du ministère de l'Environnement “Aux sources de la création du ministère de l'environnement: Des années 1950 à 1971". Pour Mem. 2013, Hors-Série, 128.

30. Cans, R.; Charvolin, F. Serge Antoine aux origines du ministère de la Protection de la nature et de l'Environnement. Pour Mem. 2008, 5, 9-18.

31. Institut Georges Pompidou. Discours de Chicago: La Crise des Civilisations; Institut Georges Pompidou: Saint-Merri, France, 2016; Available online: https://www.georges-pompidou.org/sites/default/files/pompidou_ oeuvres-choisies_2_chicago_0.pdf (accessed on 2 September 2020).

32. Poujade, R. Le Ministère de l'Impossible; Calmann-Lévy: Paris, France, 1975.

33. Becet, J.-M. La construction progressive d'un droit du littoral français (1949-1999). In Droit Maritime Français; Moreux SA: Paris, France, 1999; p. 591.

34. Auby, J.-B.; Périnet-Marquet, H.; Noguellou, R. Droit de l'Urbanisme et de la Construction, 9th ed.; Montchrestien, Lextenso éditions: Paris, France, 2012; pp. 165-171.

35. Van Lang, A. La Loi Littoral et la Protection des Espaces Naturels. Rev. Jurid. Environ. 2012, 5, $105-116$. [CrossRef]

36. Observatoire National de la Mer et du Littoral. Synthèse Statistique de la Façade Méditerranéenne; Service de l'Observation et des Statistiques du ministère de l'Ecologie: Paris, France, 2016.

37. Observatoire National de la Mer et du Littoral. Synthèse Statistique de la Façade Manche Est_-Mer du Nord; Service de l'Observation et des Statistiques du ministère de l'Ecologie: Paris, France, 2016.

38. Daligaux, J. La périurbanisation en Provence: Visages d'hier et d'aujourd'hui, interrogations pour demain. Le cas du Var et des Bouches-du-Rhône/Periurbanisation in Provence: Past and present images and question for tomorrow. The case of the Var and the Bouches-du-Rhône. Géocarrefour 2001, 76, 289-302.

39. Van den Steen, I.; Wayens, B.; Wolff, E. Evolution de l'utilisation du sol le long du littoral belge. Belgeo 2005, 3, 327-348. [CrossRef]

40. Rrapi, P. Face au bulldozer «ELAN», le Conseil constitutionnel reste de béton. Rev. Droits l’Homme 2019, 5. [CrossRef] 
41. Bordereaux, L.; Roche, C. Littoral et milieux marins. Rev. Jurid. Environ. 2018, 43, 389-408.

42. Pheulpin, S. Littoral: Les sénateurs replongent et vont plancher sur un nouveau texte. Available online: https: //www.lemoniteur.fr/article/littoral-les-senateurs-replongent-et-vont-plancher-sur-un-nouveau-texte.1945874 (accessed on 3 August 2020).

43. Bordereaux, L.; Roche, C. Littoral et milieux marins. Rev. Jurid. Environ. 2019, 44, 379-398.

44. Roche, C. Et pourtant elles tournent: La réglementation applicable aux éoliennes offshore. AJDA Dalloz Rev. 2007, 33, 1775-1792.

45. Hauser, S.J. Long Live the Heritage of Petroleum-Discoveries of Former Oil Sites in the Port City of Dunkirk. Urban Sci. 2020, 4, 22. [CrossRef]

46. Vi, B.; Calzavara, M. Covid-19 is not an opportunity to roll back environmental regulations. Available online: https://canadians.org/analysis/covid-19-not-opportunity-roll-back-environmental-regulations (accessed on 3 August 2020).

47. D'Allens, G. Le gouvernement permet aux préfets de déroger à des normes environnementales. Reporterre. 22 April 2020. Available online: https://reporterre.net/Le-gouvernement-permet-aux-prefets-de-deroger-ades-normes-environnementales (accessed on 3 August 2020).

48. Littlejohn, A. Should We Return to “Normal”? Leiden Anthropology Blog. 23 March 2020. Available online: https://www.leidenanthropologyblog.nl/articles/should-we-return-to-normal (accessed on 3 August 2020).

49. Churchman, C.W. Guest Editorial: Wicked Problems. Manag. Sci. 1967, 14, B141-B142.

Publisher's Note: MDPI stays neutral with regard to jurisdictional claims in published maps and institutional affiliations.

(C) 2020 by the authors. Licensee MDPI, Basel, Switzerland. This article is an open access article distributed under the terms and conditions of the Creative Commons Attribution (CC BY) license (http://creativecommons.org/licenses/by/4.0/). 